\title{
NEMA ZDRAVLJA BEZ DUŠEVNOG ZDRAVLJAH ŠTO JE TO DUŠEVNO ZDRAVLJE? Postoji li posve normalno ludilo, suluda normalnosti, posve normalna glupost i glupa normalnost?
}

\author{
Miro Jakovljević \\ Klinika za psihijatriju, Klinički bolnički centar Zagreb, 10000 Zagreb, Hrvatska \\ Rad je primljen 14.4.2016. \\ Rad je prihvaćen 21.4.2016.
}

\section{SAŽETAK}

Prema modificiranoj definiciji Svjetske zdravstvene organizacije duševno zdravlje je stanje potpunog tjelesnog, mentalnog, socijalnog i duhovnog blagostanja, a ne samo odsustvo duševne bolesti. Međutim, problem je što se u praksi ne definira jasno što je to duševno, socijalno i duhovno blagostanje. Duševno zdravlje je važno kako iz individualne tako i iz društvene perspektive. Neosporna je činjenica kako nema zdravlja bez duševnog zdravlja. Međutim, ne postoji općeprihvaćena definicija duševnog zdravlja što predstavlja veliku zapreku u razvoju psihijatrije i javno-zdravstvenih programa duševnog zdravlja.

O ljudima s duševnim poremećajima ne brinu samo psihijatri, nego i medicinske sestre, radni i okupacioni terapeuti, magistre/i sestrinstva, socijalni radnici te liječnici primarne zdravstvene zaštite koji su nerijetko važniji za postizanje oporavka od psihijatara.

Novije spoznaje o salutogenim procesima koji oblikuju duševno zdravlje sve više pridonose boljoj psihijatriji i medicini općenito. Zadatak psihijatrije nije samo kontrola i otklanjanje simptoma duševnih poremećaja, odnosno uspostavljanje kliničke i funkcionalne (socijalne) remisije, već potpuni personalni oporavak i što potpunije ostvarenje osobnih potencijala, mentalnog i duhovnog blagostanja.

Ključne riječi: duševno zdravlje, ludilo, normalnost.

Osoba za razmjenu informacija:

Prof.dr.sc. Miro Jakovljević

E mail: jakovljevic.miro@yahoo.com

\section{UVOD}

O ljudima s duševnim poremećajima ne brinu samo psihijatri, nego i medicinske sestre, radni i okupacioni terapeuti, magistre/i sestrinstva te liječnici primarne zdravstvene zaštite koji su važniji za postizanje oporavka od psihijatara (1). Često se može čuti kako "nema zdravlja bez duševnog zdravlja" te da je duševno zdravlje iznimno važno, kako iz individualne tako i iz društvene perspektive. Duševni poremećaji predstavljaju rizični čimbenik za mnoge tjelesne bolesti, ali i prognostički čimbenik u njihovu liječenju. S druge strane, primarno tjelesne bolesti gotovo redovito su praćene razvojem različitih duševnih poremećaja. Stoga je nedvojbena činjenica da nema zdravlja bez duševnog zdravlja. Međutim, problem je što ne postoji jedinstvena i opće prihvaćena

definicija duševnog zdravlja. Zanimljiva je i činjenica da ogromna većina udžbenika iz psihijatrije i psihopatologije uopće ne sadrži definiciju mentalnog zdravlja. Još je jako rašireno mišljenje kako se psihijatri trebaju baviti samo duševnim poremećajima, a ne i duševnim zdravljem jer tako psihijatriziraju normalne fenomene življenja. S druge strane živimo u vremenu kada se mijenjaju definicije normalnog i abnormalnog, zdravog i bolesnog, poželjnoga i poremećenoga. Premda se pojmovi „normalnost“ i „duševno zdravlje“ uglavnom koriste kao sinonimi, oni to zapravo nisu, jer normalno ne znači uvijek i zdravo. Naime, psihički normalno može se definirati kao duševno zdravlje, ali se definira i kao ono što je normirano, a najčešće označava prosječno, kao 
proces i kao utopiju. S druge strane, ono što je normalno ili uobičajeno za jednu sredinu ne mora biti i zdravo. Kao što nije uvijek lako prepoznati granicu između ludosti, zla i duševne bolesti, tako često nije jasna granica između duševnog zdravlja i bolesti.

Neki autori govore o posve normalnom ludilu Hitlera, Staljina, Kima II Sunga, Sadama Huseina, itd., te normopatima ili suludo normalnim ljudima utopljenim u masu koji formiraju vojničke redove pred nekim ogavnim predstavnikom posve normalnog ludila (1). Možda bi povijest bila posve drugačija da je provjeravano duševno zdravlje lidera velikih država, imperija i carstava, premda je teško vjerovati da bi ijedan moćnik dopustio da se provjerava njegovo duševno zdravlje (2). U naše vrijeme posve normalna glupost razvila se u zasebnu struku preko sredstava masovnih medija, glupo normalni koji sebe smatraju oličenjem normalnosti sve više se množe, a samo nas dobar humor može osloboditi od svijeta glupo normalnih (1). Ili pak samo uistinu znastveni pristup u shvaćanju i definiranju duševnog zdravlja i duševnih poremećaja? Prema Normanu Sartoriusu znanje stečeno na području mentalnog zdravlja moglo bi pridonijeti sveukupnom socioekonomskom razvoju, a jedna od najvećih zapreka razvoju psihijatrije i programa duševnog zdravlja jest nejasnoća i konfuzija njihovih temeljnih koncepata (3).

\section{MEDICINSKO-KLINIČKI PRISTUP}

Duševno zdravlje je važna sastavnica zdravlja, pa je onda logično da se prvo definira zdravlje. U literaturi se mogu naći sljedeće definicije zdravlja: 1 . zdravlje je odsutnost bolesti, nemoći, patnje (muke, boli) ili oštećenja; 2 . zdravlje je stanje organizma koje omogućuje osobi sve aktivnosti primjerene njenoj dobi, spolu, socijalnom statusu, odnosno njenim ulogama i kulturnom određenju; 3. zdravlje je stanje ravnoteže, homeostaze ili ekvilibrija u samoj osobi te između nje i njezinog socijalnog i fizičkog okruženja; 4 . zdravlje je stanje potpunog tjelesnog, mentalnog, socijalnog i duhovnog blagostanja (4).

Prema modificiranoj definiciji Svjetske zdravstvene organizacije (SZO), duševno zdravlje je stanje potpunog tjelesnog, mentalnog, socijalnog i duhovnog blagostanja, a ne samo odsustvo duševne bolesti. Međutim, problem je što se u praksi ne definira jasno što je to duševno, socijalno i duhovno blagostanje. Prema pragmatičnoj definiciji osobe koje ne traže psihoterapeutsku ili psihijatrijsku pomoć i ili koje nemaju psihijatrijsku dijagnozu duševno su zdrave osobe. Na prvi je pogled jasno kako se radi o površnom zaključivanju i pogrešnom pristupu. Zbog stigme, neobaviještenosti i mnogih drugih razloga ne traži se psihijatrijska pomoć pa se ne može ni postaviti dijagnoza duševnog poremećaja. Prema pragmatičnoj definiciji duševno zdravlje je odsustvo poremećaja duševnih funkcija i simptoma duševnog poremećaja, a dijagnoza duševnog poremećaja postavlja se na temelju dogovorenih dijagnostičkih kriterija za pojedine duševne poremećaje. Duševni poremećaji su raznovrsni, prema MKB-10 razvrstani su u deset kategorija, a mogu se očitovati 1. neprimjerenim ili neočekivanim ponašanjem, doživljavanjem i mišljenjem, 2 . kršenjem društvenih i kulturnih normi, 3. osobnom patnjom, 4. smetnjama u socijalnom, radnom i obiteljskom funkcioniranju. Ovaj je pristup praktičan, ali ne govori ništa o tomu što duševno zdravlje jest, što su njegove sastavnice, zašto je ono važno, već samo što ono nije, što ono isključuje, a to je duševni poremećaj. Stoga je nužno definirati duševno zdravlje tako da definicija sadrži sve ono što duševno zdravlje uključuje kao i sve što duševno zdravlje isključuje, te isto tako jasno definirati fizičko, duševno, socijalno i duhovno blagostanje. Prema N. Sartoriusu zdravlje treba promišljati kao "stanje u kome pojedinac postiže stanje ravnoteže u sebi i s okolinom, stanje koje mu omogućuje izvršenje socijalnih i osobnih zadaća, stanje u kome su bolesti kontrolirane ili odsutne" (4).

\section{HUMANISTIČKO-FILOZOFSKI PRISTUP}

Duševno zdravlje tijesno je povezano s realizacijom autentičnih ljudskih potencijala i istinskih, a ne lažnih potreba koje se nameću izvana. Čovjek je u svojoj biti stvoren kao dobar, a ne zao kakvim ga čine kulture laži i izrabljivanja. Problem je u tomu što do sada niti jedno društvo nije osiguralo uvjete za čovjekovo potpuno samo-ostvarenje. Utemeljitelji ovog pristupa su Erih Fromm, Herbert 
Marcuse i Abraham Maslow. Preokupacija zadovoljavanjem lažnih potreba dovodi do oblikovanja lažnog ja i otuđenja od svojih autentičnih potencijala, što može biti put u duševni poremećaj. U knjizi „Zdravo društvo“ Fromm navodi pet važnih specifičnih ljudskih potreba: 1. pripadnost i društvenost nasuprot narcisizmu, 2. kreativnost (stvaralaštvo) nasuprot destruktivnosti (razaranju), 3. bratstvo nasuprot rodoskrvnjenja, 4. individualnost i osjećaj osobnog identiteta nasuprot konformizma horde, i 5. razum nasuprot iracionalnosti (5). Prema Maslowu samoostvarenje se očituje ostvarenjem potencijala koji su sadržani u „unutarnjem ja“, ali ljudsku prirodu lako nadvladaju navike, kulturni pritisak i pogrešni stavovi prema njoj. Duševno zdravlje očituje se kroz dobru percepciju stvarnosti, stupanj prihvaćanja sebe i drugih, stupanj spontanosti, sposobnost fokusiranja problema, sposobnost distanciranja i privatnosti, stupanj autonomije i otpora enkulturaciji, te kroz dobru procjenu aktualne situacije.

\section{POZITIVNO-PSIHOLOŠKI PRISTUP}

Duševno zdravlje neodvojivo je povezano s pozitivnom psihologijom, osjećajem vlastitog blagostanja i dobrobiti, sreće i zadovoljstva životom. Među istaknutijim predstavnicima ovog pristupa su Carol D. Ryff, Corey L.M. Keyes, Martin E.P. Seligman, Mihaly Csikszentmihalyi, R.C. Cloninger, ali i i mnogi drugi. Subjektivna dobrobit, odnosno duševno zdravlje očituje se kroz 1. prihvaćanje sebe i pozitivan stav prema sebi, 2 . zadovoljavajuće i empatične odnose s drugim ljudima koji podrazumijevaju i davanje i primanje, 3. visok stupanj autonomije i neovisnosti, vlastite visoke standarde i unutarnju kontrolu, 4. visok stupanj kompetencije i utjecaja na okolinu, kreiranja povoljnog konteksta i korištenja prilika, 5. primjerene životne ciljeve, osjećaje i vjerovanja koja daju autentični smisao životu, 6. osobni rast i razvoj, te otvorenost za nova iskustva. Robert C. Cloninger je razvio psihoterapijski program koji uključuje 15 modula intervencije kako da ljudi ostvare stanje veće dobrobiti i postanu zdraviji i sretniji, a Martin Seligman koncept naučenog optimizma kojim se može postići autentična sreća. Prema M. Seligmanu autentična sreća uključuje četiri tipa dobrog života: 1 . ugodan život koji uključuje postojanje pozitivnih emocija u najvećoj mogućoj mjeri i učenje vještina kojima se produljuje i intenzivira zadovoljstvo i ugoda; 2. predan život koji se očituje u poznavanju svojih sposobnosti i njihovoj realizaciji u radu, ljubavi, prijateljstvu, igri i roditeljstvu u što većoj mjeri, 3. smislen život koji se sastoji u pripadanju, predanosti i služenju nečemu većemu od nas samih, 4. uspješan život koji se očituje postizanjem poželjnih ciljeva $(6,7)$. Odnos duševnog zdravlja i sreće praćen je cijelim nizom zanimljivih pitanja. Je li osjećaj sreće mjerilo duševnog zdravlja? Je li duševno zdravlje preduvjet autentične sreće? Jesu li nesretni ljudi duševno poremećene ili bolesne osobe? I obrnuto, jesu li svi sretni ljudi duševno zdravi? Za Kecmanovića sreća je, za razliku od duševnog zdravlja, isključivo subjektivni fenomen, a osjećaj nezadovoljstva također može biti pokazatelj duševnog zdravlja (8). Ovdje je važno skrenuti pozornost na pojmove lažne i autentične sreće, te istinskog i prividnog duševnog zdravlja. Stoga treba razlikovati hedonički (grč. hedone - zadovoljstvo, naslada) model duševnog blagostanja koji uključuje prevladavanje pozitivnog afektiviteta nad negativnim, subjektivnu sreću i zadovoljstvo životom koje može biti globalno i specifično za određene oblasti života od eudaimoničnog (grč. eudaimon - blažen, sretan) modela duševnog blagostanja koji uključuje prihvaćanje sebe, pozitivne odnose s drugima, autonomiju, usklađenost $s$ okolinom, smisao života i osobni rast. Prema Keyes-u duševno zdravlje uključuje tri povezane, ali različite sastavnice: 1 . hedonično blagostanje ili dobrobit, 2. individualnu eudaimoničnu dobrobit i 3. socijalnu eudaimoničnu dobrobit. Socijalna eudaimonična dobrobit podrazumijeva optimalno funkcioniranje koje dovodi do socijalnog ispunjenja što ga karakterizira socijalna koherencija (npr. sposobnost razumijevanja/ shvaćanja funkcioniranja svoje zajednice), socijalno prihvaćanje (npr. prihvaćanje drugih), socijalna aktualizacija (npr. optimistični pogled na potencijale svoje zajednice), socijalni doprinos, npr. osjećaj doprinosa općem dobru svojim aktivnostima i 
socijalna integracija, npr. osjećaj pripadnosti svojoj zajednici (9).

\section{DEFINICIJA DUŠEVNOG ZDRAVLJA PREMA SZO}

Duševno zdravlje je stanje dobrobiti i blagostanja kada osoba realizira svoje potencijale, može se nositi s normalnim životnim stresovima, može raditi produktivno i uspješno, i može pridonositi dobrobiti svoje zajednice (10).

\section{TRANSDISCIPLINARNI HOLISTIČKI PRISTUP}

Psihijatrija je znanstvena i primijenjena medicinska disciplina u kojoj se više ili manje kreativno susreću medicina, neuroznanost, filozofija i religija $(11,12)$. Odsustvo boli, muke, patnje i bolesti u negativnom, a prisutnost osjećaja dobrobiti, vitalnosti i kreposti u pozitivnom izričaju definiraju zdravlje. Preventivna medicina nam pomaže saznati „što nam je potrebno za zdrav život”, neuroznanost "kako funkcionira zdrav mozak“, a filozofija, čija je važna sastavnica i etika, „što trebamo za dobar, sretan, mudar i smislen život", dok preventivna psihijatrija, koja je poprilično zanemarena, daje odgovor na pitanje „što nam je potrebno za duševno i duhovno zdravlje”.

Prema transdisciplinarnom holističkom i integrativnom modelu autora ovoga teksta duševno zdravlje odražava zastupljenost i interakciju salutogenih i patogenih procesa i čimbenika. Salutogeni procesi (circulus virtuosus) dovode do duševnog zdravlja i njegova unapređenja, a psihopatogeni procesi (circulus vicious) vode u duševni poremećaj. Duševno je zdravlje određeno nečijom vulnerabilnošću, rezilijencijom (sposobnošću ponovnog uspostavljanja sklada i ravnoteže, odnosno povratka u normalno stanje) i psihosocijalnim i duhovnim potencijalima za osobni rast i razvoj. Duševno zdravlje povezano je sa zdravljem mozga, njegovim dobrim funkcioniranjem i primjerenim mentalnim funkcijama, ali i s općim tjelesnim zdravljem, zatim s pozitivnim psihobiološkim programom koji uključuje pozitivna vjerovanja o sebi, svijetu i smislu života, ostvarenjem autentičnih potencijala osobe i doživljajem uspjeha i sreće, pozitivnim i kreativnim mišljenjem, zdravim stilovima življenja i kvalitetom interpersonalnih odnosa, uspješnom realizacijom profesionalnih i životnih uloga u sklopu ostvarenja svoje autentične životne misije.

Imajući u vidu različite definicije koje se mogu naći u literaturi može se reći da duševno zdravlje uključuje određene vještine, karakteristike i ponašanja kao što su: 1 . sposobnost da se živi produktivan $\mathrm{i}$ ispunjen život, 2. dobra mentalizacija i ispravna procjena stvarnosti; 3. sposobnost da se voli, radi i surađuje s drugima, 4 . prilagodba na svijet $\mathrm{i}$ skladan odnos sa sobom i drugima, 5. osjećaj zadovoljstva i sreće, 6 . mogućnost učenja, osobnog rasta i razvoja, 7. sposobnost ponovnog uspostavljanja ravnoteže (dinamičke homeostaze) nakon stresnih i traumatskih događaja i situacija (reziliencija) koja omogućuje uživanje u životu i prevladavanje boli, razočaranosti i tuge, 8 . sposobnost transcendencije (duhovna dimenzija zdravlja), 9. osjećaj povjerenja, kompetencije, postignuća, humora, 10. sposobnost upravljanja svojim ponašanjem i kontrola impulsa koji mogu imati aktualno ili potencijalno štetan učinak na okolinu i druge članove zajednice, 11. sposobnost uspostavljanja kreativnih i poželjnih interpersonalnih odnosa i razumijevanja potreba pripadnika drugih rodnih, rasnih, etničkih, nacionalnih, vjerskih, političkih skupina, itd. Drugim riječima duševno zdravlje je povezano s pozitivnim, kreativnim i eudaimoničnim selfom tako da duševno zdrava osoba ima osjećaj samopoštovanja i poštuje druge, prihvaća svoje i dobre i loše strane, autentično je zainteresirana za druge ljude i solidarna s njima, ima sposobnost samokontrole i povezivanja i udruživanja s drugim ljudima, ima primjerenu percepciju realiteta i ciljno usmjerenje u životu, prilagođena je svojoj okolini, sposobna je za radost i sreću.

Za prikaz transdisciplinarnog integrativnog model duševnog i duhovnog blagostanja može korisno poslužiti SWOT (Strength - snaga; Weakness - slabost; Opportunity - povoljna prilika; Threat - prijetnja) analiza (shema 1). 


\begin{tabular}{lll}
\hline & $\begin{array}{l}\text { Korisno za duševno } \\
\text { blagostanje }\end{array}$ & Štetno za duševno blagostanje \\
\hline Osobni potencijali & Snaga & Slabost \\
& Ljubav & Nedostatak ljubavi \\
& Duhovnost & Vulgarni materijalizam \\
& Smisao života/poslanje & Gubitak smisla/besmisao \\
& Optimizam & Pesimizam \\
& Kreativnost & Destruktivnost \\
& Pozitivne emocije & Negativne emocije \\
& Zahvalnost & Nezahvalnost \\
& Moć za dobro & Bespomoćnost/nemoć \\
& Povoljne prilike & Prijetnje i prepreke \\
& Nagrada & Kazna \\
& Uspjeh & Neuspjeh/poraz \\
& Dobitak & Gubitak \\
& Sigurnost & Nesigurnost/opasnost \\
\hline
\end{tabular}

Shema SWOT model duševnog blagostanja

Duševno zdravlje odražava složene interakcije između osobina, snaga i slabosti osobe s jedne strane i utjecaja okoline kroz povoljne prilike i prijetnje blagostanju osobe. Njegovanje vrlina i karakterna snaga osobe (vidjeti tablicu 1) i povoljne prilike predstavljaju salutogene čimbenike, dok su karakterne slabosti osobe i prijetnje iz okoline povezane s psihopatogenim procesima.

Tablica 1. Vrline i njihova povezanost s karakternom snagom osobe (Peterson \& Seligman 2004)

\begin{tabular}{ll}
\hline Vrlina & Karakterna snaga \\
\hline Mudrost & Kreativnost (originalnost, dosjetljivost) \\
& Znatiželjnost (zanimanje za novo) \\
& Otvorenost uma (kritičko mišljenje i sposobnost promjene \\
& stava na temelju činjenica) \\
& Ljubav prema učenju (sistematično i iznad znatiželje) \\
& Vidik, perspektiva (sposobnost razumijevanja svijeta) \\
& Odvažnost (fizička i moralna) \\
Hrabrost & Ustrajnost (aktivnost do postizanja cilja) \\
& Integritet (iskrenost, poštenje, istinoljubivost i autentičnost) \\
& Vitalnost (entuzijazam, energija, vedrina, bodrost) \\
& Ljubav (sposobnost uspostavljanja bliskih i recipročnih \\
Humanost & odnosa) \\
Čovjjěnost & Ljubaznost (suojjećajnost, skrb za druge) \\
& Socijalna inteligencija (emocionalna inteligencija) \\
Pravednost & Građanska kultura (socijalna odgovornost i imski rad) \\
& Pravičnost (davanje jednakih šansi svima) \\
& Lideršip (organiziranje grupa djelotvorno i pravično)
\end{tabular}

Razboritost Opraštanje i milosrđe (neosvetoljubivost i pružanje druge prilike) Poniznost/umjerenost (održavanje realističnog self-koncepta) Razboritost (validna procjena rizika i izbjegavanje nepotrebnog rizika) Samo-regulacija (disciplina i samo-kontrola)

Transcendentnost Priznavanje i poštivanje ljepote i izvrsnosti (u svim oblasti$\mathrm{ma})$

Zahvalnost (biti svjestan pomoći drugih i izraziti zahvalnost) Nada (očekivanje najboljeg i predanost postizanju najboljeg) Humor (razigranost i gledanje svijetle strane u svakoj situaciji)

Duhovnost (držanje koherentnih i čvrstih vjerovanja o smislu života)

Većina ljudi sposobna je stvarati pozitivne želje, ali često pozitivnoj želji pridruži pesimizam ili negativne emocije, primjerice strah od neuspjeha, i tako sebi uskrati blagostanje uspjeha i ostvarene želje. Da bi netko ostvario svoju želju, nužno je da ona bude praćena optimizmom, pozitivnom emocijom, pozitivnim mišljenjem i kreativnim ponašanjem. $\mathrm{Za}$ optimistu problemi i prepreke su izazovi na putu ostvarenja svojih želja i zadovoljenja autentičnih potreba, a za pesimistu svaki izazov predstavlja problem. Kada prepreke iz okoline proizvode strah ili pesimizam koji je veći od želje da se postigne cilj, do cilja se neće doći. Mnogi ljudi ne rade ono što vole ili žele, nego ono što misle da moraju ili trebaju raditi. Tiranija glagola morati ili trebati gotovo redovito djeluje nepovoljno na duševno blagostanje. Raditi ono što volimo i voljeti ono što radimo povezano s ostvarenjem naših autentičnih potencijala značajno pridonosi našoj samoaktualizaciji i duševnom blagostanju. Nagrada za dobro djelo je u samom činjenju dobrog djela. Iz svega navedenog može se zaključiti kako duševno zdravlje odražava uspješnost korištenja povoljnih prilika i svladavanja prepreka u procesu samoaktualizacije i kreativne realizacije vlastitih potencijala psihosocijalnog i duhovnog rasta $\mathrm{i}$ razvoja.

\section{ZAKLJUČAK}

Duševno zdravlje je važno kako iz individualne tako i iz društvene perspektive. Neosporna je činjenica kako nema zdravlja bez duševnog zdravlja. Međutim, ne postoji općeprihvaćena definicija duševnog zdravlja što predstavlja veliku zapreku u 
razvoju psihijatrije i javno-zdravstvenih programa duševnog zdravlja. Novije spoznaje o salutogenim procesima koji oblikuju duševno zdravlje sve više pridonose boljoj psihijatriji i medicini općenito. Zadatak psihijatrije nije samo kontrola i otklanjanje simptoma duševnih poremećaja, odnosno uspostavljanje kliničke i funkcionalne (socijalne) remisije, već potpuni personalni oporavak i što potpunije ostvarenje osobnih potencijala, mentalnog i duhovnog blagostanja.

\section{LITERATURA}

1. Luetz M. Ludilo - Liječimo pogrešne: pravi problem su normalni ljudi. Zagreb: Znanje; 2011.

2. Kecmanović D. U potrazi za identitetom psihijatrije IV. Beograd: Clio; 2014.

3. Sartorius N. Borba za duševno zdravlje. Zagreb: Pro Mente \& Profil; 2010.

4. Sartorius N. Zdravlje i bolest. U: Klain E, ur. Psihološka medicina, 21-35. Zagreb: Golden marketing; 1999.
5. Fromm E. Zdravo društvo. Beograd: Rad; 1963.

6. Cloninger CR. Feeling Good-The Science of Well-Being. Oxford University Press; 2004.

7. Seligman M. Authentic Happiness. New York: Free Press; 2003.

8. Kecmanović D. Očima psihijatra. Beograd: Clio; 2010.

9. Moneta GB. Positive Psychology - A Critical Introduction. New York: Palgrave Macmillan; 2014.

10. World Health Organization. Promoting Mental Health: Concepts, Emerging Evidence, Practice. Geneva; 2005.

11. Jakovljević M. Transdisciplinary holistic integrative psychiatry - A wishful thinking or reality? Psychiatria Danubina. 2008;20:341-48.

12. Jakovljević M i sur. Duševno zdravlje, kultura i društvo - Izazovi pred psihijatrijom. Zagreb: Pro Mente; 2013. 


\title{
THERE IS NO HEALTH WITHOUT MENTAL HEALTHH WHAT IS MENTAL HEALTH? \\ Is there a perfectly normal madness, insane normality, quite normal stupidity and stupid normality?
}

\author{
Miro Jakovljević \\ Department of Psychiatry, University Hospital Center Zagreb, 10000 Zagreb, Croatia
}

\begin{abstract}
According to the modified definition of the World Health Organization mental health is a state of complete physical, mental, social and spiritual well-being and not merely the absence of mental illness. However, the problem is that, in practice, this does not clearly define what mental, social and spiritual well-being is. Mental health is important from both an individual and a social perspective. It is an indisputable fact that there is no health without mental health. However, there is no universally accepted definition of mental health, which represents a major obstacle in the development of psychiatry and public health programs of mental health. Psychiatrists are not the only ones taking care of patients with mental disorders, there are also nurses, occupational workers and therapists, Masters of nursing, social workers and primary care physicians who are often more important to achieve recovery than the psychiatrists themselves. Recent knowledge on salutogenetic processes that shape mental health is increasingly contributing to a better psychiatry and medicine in general. The task of psychiatry is not only the control and elimination of the symptoms of mental disorders, or the establishment of clinical and functional (social) remission, but complete personal recovery and as fully as possible the realization of personal potential, mental and spiritual well being.
\end{abstract}

Key words: mental health, insanity, normality

Correspondence: Miro Jakovljević, $\mathrm{PhD}$

E mail: jakovljevic.miro@yahoo.com 